Article

\title{
Rethinking the Governance of the 2030 Agenda for Sustainable Development in the COVID-19 Era
}

\author{
Francisco Santos-Carrillo ${ }^{1}\left[\right.$, Luis A. Fernández-Portillo ${ }^{2, *(\mathbb{D}}$ and Antonio Sianes ${ }^{3(\mathbb{C}}$ \\ 1 Department of International Studies, Universidad Loyola Andalucía, 14004 Cordoba, Spain; \\ frsantos@uloyola.es \\ 2 ETEA Foundation-Development Institute, Universidad Loyola Andalucía, 14004 Cordoba, Spain \\ 3 Research Institute on Policies for Social Transformation, Universidad Loyola Andalucía, 14004 Cordoba, \\ Spain; asianes@uloyola.es \\ * Correspondence: portillo@uloyola.es; Tel.: +34-957-222-100
}

Received: 18 August 2020; Accepted: 14 September 2020; Published: 17 September 2020

check for updates

\begin{abstract}
The 2030 Agenda for Sustainable Development has been criticized for its institutional weakness. It assumed that governance commitments and the multilateral order would remain unchanged until 2030. The COVID-19 has challenged both assumptions. The response deployed by the countries has made international cooperation dependent on the solution of internal problems. What will be the impact of the pandemic on the 2030 Agenda and the Sustainable Development Goals? What changes can be expected in the institutional design of the Agenda to face this challenge? To address these questions we have gathered and systematized 152 documents issued by the top think tanks on International Development since the outbreak of COVID-19, to identify the main design features of the Agenda that should be modified according to the functional-rationalist approach to institutional design. Our study shows that a higher level of centralization of authority and a redefinition of control and flexibility mechanisms are needed in order to improve the governance of the Agenda. Despite the temptation of focusing on a narrow set of goals, a broad scope is recommended, necessary to safeguard its holistic approach. These findings can provide insights for addressing the governance and institutional design of other international arrangements of similar nature.
\end{abstract}

Keywords: 2030 Agenda; COVID-19; global governance; international institutions; institutional design; argument mining; NVIVO

\section{Introduction}

The COVID-19 crisis has become a double threat to the 2030 Agenda. On the one hand, the impact on developing countries can be a setback in terms of poverty reduction, food security, and global health, making it more difficult to achieve the Sustainable Development Goals (SDGs). On the other hand, this crisis has highlighted the vulnerability of global governance and the current multilateral system. The responses to the crisis seem to subordinate international cooperation to the solution of internal problems. However, many states, mainly in the Global South, do not have the resources to address them.

The 2030 Agenda shows some weaknesses in terms of domestic and global governance. In fact, it has no rules to reconcile the implementation at both levels and to prevent the former from strangling the latter, to the detriment of developing countries. The institutional design of the Agenda is configured as a set of general non-binding principles and guidelines that transfer the responsibility for implementation to governments and national actors [1].

At the domestic level, it requires a complex approach to decentralized multi-actor governance, which will favor the most powerful groups and risks to concentrate governments' efforts on their 
domestic interests [2]. However, even this model is threatened by emergency and national reconstruction narratives, and it is likely that governments will choose to allocate national resources to other priorities not directly related to the Agenda [3]. At the international level, it requires maintaining, if not strengthening, the international community's solidarity-based commitment to multilateralism, especially with regard to the implications of high-income countries for Official Development Assistance (ODA). Unfortunately, the actions that are taking place seem to be going in the opposite direction, which would represent another significant setback for developing countries. The Agenda assumed that the governance commitments would be held in the multilateral order under the premise that both the commitments and the order would remain unchanged. The COVID-19 crisis threatens these assumptions [4].

Before the outbreak of the COVID-19 crisis, the academic community and experts had been showing concern about the future of the Agenda. They had also criticized its institutional weakness and the vagueness of its political arrangements $[5,6]$. The leadership exerted by some countries and the resistance showed by multilateralism kept it alive. Nevertheless, recent evaluation reports indicate difficulties in progress [7] and risks to compliance in some regions [8]. The uncertainty generated with the COVID-19 crisis has significantly increased the already existing concerns about the potential of the 2030 Agenda to be an effective instrument of development worldwide [6,9].

While the community of states may be comfortable with such soft arrangements, this may no longer be possible in the face of the need for more effective cooperation [10]. In a context of governance dominated by forces that hinder cooperation, the institutional nature of the Agenda would probably require further strengthening and more precise and binding rules to make the commitments more credible.

Based on this hypothesis, the aim of this paper is to find early evidence for the capacity of the Agenda to cope with the changes in global governance that the COVID-19 could bring about, with an attempt to answer the following questions: What is the expert community's opinion about the impact of the pandemic on global governance and the multilateral order? How will this new order affect the implementation of the Agenda and the SDGs? Is an adaptation of the institutional design of the Agenda required to continue being a relevant reference framework for multilateral cooperation in the coming years? In what direction should the governance of the Agenda be adapted to face the changes that are appearing on the horizon after the COVID-19 crisis?

The 2030 Agenda is a United Nations General Assembly resolution approved by the head of state and government and high representatives, establishing a set of 17 SDGs. The Agenda is a constitutive rule of a global action on sustainable development, based on solidarity and collaboration among international actors, who assume the commitment of its implementation under their own rules [1]. As a resolution based on an exhortatory agreement, its legal status and institutional nature generate controversy, although there is a certain level of consensus among the specialized academic community.

Regarding its legal status, it is a norm that can be interpreted as a body of international law even as soft law, suggesting a legally binding authority in different degrees, which varies according to the context, the subject matter or its incorporation as a norm derived by the states themselves by virtue of their practice [11-13].

With regard to the controversy, the debate arises because of the weakness of its rules. Theory defines an international institution as a set of explicit formal and informal agreements and rules that govern the behavior of actors by limiting and restricting, but also prescribing, requiring, or allowing their activities and behavior [14-17]. Koremenos et al. [18] define international institutions as explicit agreements, negotiated between international actors, that prescribe, proscribe, and/or authorize behaviors. Therefore, it is commonly accepted that it is impossible to establish qualification criteria on the basis of explicit or implicit rules, on the characteristics that grant greater efficiency or on the social construction of the rules [17]. The issue is that actors should guide their cooperation by norms or rules in a persistent way. This is shown by an important part of the empirical literature, which analyses within the same framework international agreements of different nature and level of institutionalization [19,20], including the High-Level Forum on Sustainable Development [21]. 
As an international institution that calls all stakeholders to an intersubjective and self-regulating process, the Agenda has a clear constructivist and multilateral character [22-24]. However, the open interpretation of the rules and their non-binding character entail compliance risks when there are changes in the interests of the actors that encourage the modification of their behavior. This weakness in institutional design can be counteracted with the help of rational functionalism, offering alternatives that improve compliance expectations and justify the maintenance of international institutions such as the Agenda $[17,18,25]$.

For rational functionalism, the design of institutions is a rational creation of states and other international actors to promote their common interests [18]. By focusing on the interest of the actors, it offers a substantive response to address global governance problems. The designs of international institutions explain the variation in institutional forms and show their capacity to influence their results $[18,19,26,27]$.

However, conceptually linking institutional design to the rationality of results has epistemological repercussions that favor but also limit analysis, which is why this approach has been criticized. The criticism, which we share in some respects, concerns issues related to both the application of rationality and design aspects [17]. As for rationality, recurrent criticisms include the inability to incorporate contingent factors into the design at the constitutional moment of an institution or the impositions and resistances of path dependence in the conciliation of conflicting interests [28,29]. As far as design is concerned, the idea of a unique and recognizable designer is questionable, and it is difficult to demonstrate the ability of designers to choose designs intentionally in the face of structural constraints. The nature of institutional design seems to respond, rather, to an incremental logic where the negotiation between the actors involved in the political game determines the possibilities [17,30,31].

Therefore, the establishment of rational designs may in some cases appear to be highly unlikely. However, in open processes, opportunities arise for possible episodes of reform. The logics of appropriateness and consequences can then emerge as complementary, despite the tendency of an important part of the academy to consider them as exclusive [30]. At times, when there are problems of effectiveness and uncertainty about the behavior of the actors, possibilities for rational institutional reforms arise [32]. This could be the moment the 2030 Agenda is at right now.

Undoubtedly, the COVID-19 pandemic has changed the rules of the game in a dramatic way, and for that reason, a reflection on the institutional design of the Agenda is needed. To understand how the global arena has changed due to the COVID-19 crisis and how the institutional design of the 2030 Agenda should be adapted to remain a relevant frame of reference for multilateral cooperation, we need evidence about the former and a theoretical framework for the latter.

In the next section, we describe the methodology used, based on content analysis of the opinion of relevant international development experts regarding the changes brought about by COVID-19. The third section presents and discusses the results of the analysis, in terms of how those changes may impact the institutional design of the Agenda. Finally, we present the conclusions and some future lines of research.

\section{Materials and Methods}

\subsection{Database for the Analysis}

When expert-based research is conducted, the selection criteria are a critical aspect, as they determine the scope and the capacity of generalization of the results.

To select the experts, we rely on the concept of epistemic communities, used regularly in the discipline of International Relations for the analysis of international institutions and organizations [33-35]. An epistemic community is defined as a network of professionals or experts with recognized experience and competence in a particular field and who also have sufficient legitimacy in the policy area within a given field [33]. In this paper, we focus on experts in international development policy working of the main think tanks on the topic. Their position invites to consider their opinion about the impact of 
COVID-19 on the world as informed and qualified. The identification of such experts is also supported by the privileged position think tanks currently occupy in public debate, reflected in their access to mainstream media and the recognition of their political opinions as independent [36]. Think tanks have become involved in policy delivery, a fact that explains why they have been extensively used as a source of research [37-41].

According to Kelstrup [42], when selecting think tanks for an analysis of this kind, traditional sampling techniques cannot be used, and 'maximalist' approaches should be avoided, among other reasons, because there are many think tanks that are inactive, and the quality of their research is not homogeneous. For this reason, we have referred to the 2019 Global Go To Think Tank Index Report [43], the most widespread source to identify relevant think tanks in different categories.

In the existing literature, no satisfactory criterion as to how many think tanks should be considered for this type of research has been found. Articles that use think tanks as a source of information use different numbers. For example, Shaw et al. [44] use 4 with respect to health policy; Haas [45] includes 7; McCright and Dunlap [46] work with a final sample of 14; and Boussalis and Coan [47] base their analysis on 19. In our research, we chose the first 15 think tanks plus the center of excellence for the period 2016-2018 in the International Development category. The list includes organizations that range from the Korea Development Institute (center of excellence) to the Overseas Development Institute (top 15), including well-known Western and Eastern think tanks, from developed and developing countries.

Regarding the time period considered, the literature recommends a cross-sectional analysis for this type of research [48], as it is focused on the early vivid debate around the consequences of COVID-19 for the world, mainly generated once the coronavirus hit the Western world. Thus, the documents retrieved to build our database concentrate on the period from March 12 to April 16. The starting day was chosen as the day after the World Health Organization declared COVID-19 as a global pandemic. The closing day was slightly extended from an initially intended one-month period due to the relatively later landing of the COVID-19 debate in the United States (US) and some developing countries. Even though there were few contributions before this period, and certainly they continue afterwards, no more than one month was necessary. The chosen period offers a deep overview of the topic, as the production of documents in the days after the outbreak was significantly higher than usual.

Only contributions written in English were included, as English is the dominant language in the international debate.

The search sequence of the documents was as follows. First, the official website of each think tank was accessed. Then, a search has been made based on the main topic, "COVID" or "coronavirus". We selected those documents whose content linked the topic to the themes of global governance, international politics, international cooperation, and world order. We have discarded those documents related to domestic issues of a given country or sector without any link to the problem of global governance, international cooperation, or international relations in general. Thirdly, we filtered only and exclusively the opinion documents of experts directly linked to the think tank or who are regular collaborators of that institution, according to the information contained on the website itself. These opinion documents appear under different formats and typologies: Articles, comments, publications, or blog entries. Any other type of entry, such as news on the evolution of the pandemic, working papers, summaries, interviews, podcasts, webinars, or any other format different from those mentioned, have been ruled out. Finally, entries from invited experts and articles imported from other websites were also discarded.

Once the search strategy was performed and finished, we gathered a total of 152 documents according to the selection criteria. Their analysis allowed us to gather the views of international development experts about a wide range of aspects of the expected implications of COVID-19 for the world (Figure 1). 


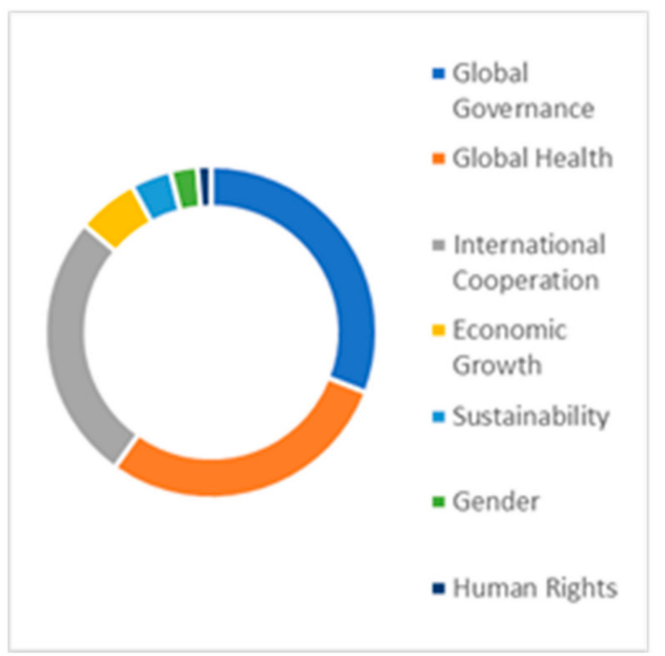

(a)

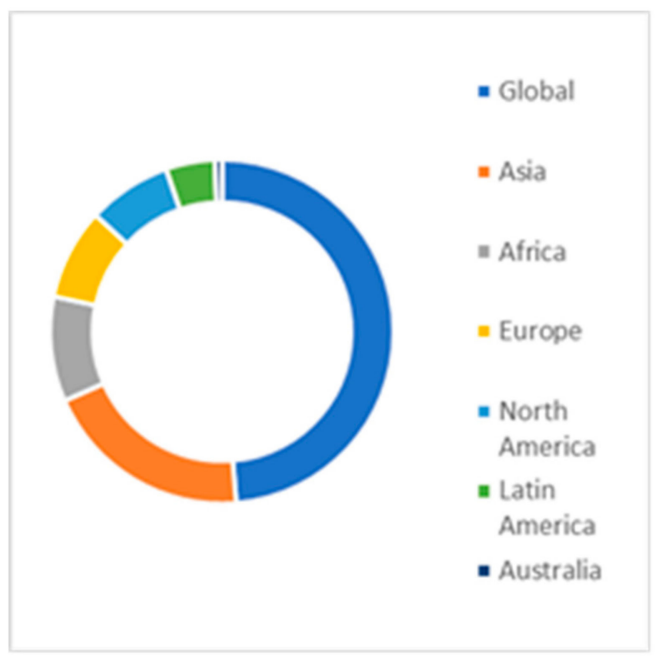

(b)

Figure 1. Profiles of contributions by experts. (a) Thematic; (b) geographic.

Figure 1 shows how the distribution and coverage of the documents in the database is representative enough to distil the opinion of experts about the multidimensional implications of the pandemic in the global arena. The distribution of the documents should not necessarily cover all intersections. In fact, it is interesting to note gaps and overlaps. In Table 1, we can see how global health issues are concentrated in Asia and Africa, while Europe and North America mainly address issues of international cooperation.

Table 1. Thematic versus geographic scope of the documents.

\begin{tabular}{|c|c|c|c|c|c|c|c|c|}
\hline Region & $\begin{array}{c}\text { Global } \\
\text { Governance }\end{array}$ & $\begin{array}{l}\text { Global } \\
\text { Health }\end{array}$ & $\begin{array}{l}\text { International } \\
\text { Cooperation }\end{array}$ & $\begin{array}{l}\text { Economic } \\
\text { Growth }\end{array}$ & Sustainable & Gender & $\begin{array}{l}\text { Human } \\
\text { Rights }\end{array}$ & Total \\
\hline Global & 24 & 12 & 26 & 4 & 5 & 3 & & 74 \\
\hline Asia & 14 & 9 & 4 & 1 & & & 2 & 30 \\
\hline Africa & 1 & 10 & & 3 & & 1 & & 15 \\
\hline Europe & 2 & 4 & 7 & & & & & 13 \\
\hline North America & 2 & 5 & 3 & 1 & 1 & & & 12 \\
\hline Latin America & 3 & 4 & & & & & & 7 \\
\hline Australia & 1 & & & & & & & 1 \\
\hline Total & 47 & 44 & 40 & & 6 & 4 & 2 & 152 \\
\hline
\end{tabular}

The analyses realized show how the database of documents, despite potential slight biases, covers a wide range of topics. During this article, we will refer to these documents using their code in brackets (note that only some examples of documents addressing each category will be quoted). The list of documents with their codes can be found in the Table A1 in Appendix A.

\subsection{Methodology}

Our methodological approach relies on the rational-functionalist model developed two decades ago by Koremenos et al. [18] and subsequently updated by Koremenos [19,32,49]. The model tries to systematically infer how the configuration of a series of exogenous contextual factors (those underlying cooperation problems that the actors are facing, and the characteristics of these actors), called independent variables, should impact the institutional design (dependent variables) of international institutions [18,19]. This model allows for forecasting analyses, assuming that the actors adopt rational behavior. The connections between independent and dependent variables are carried out using a set of theoretical assumptions called 'conjectures', whose validity has been quantitatively evaluated in different n-large studies (e.g., [50,51]). Nevertheless, in this paper, we are dealing only with one case, 
the 2030 Agenda, so the relationship between contextual factors and institutional design cannot be established quantitatively. Instead, we can take advantage of the lessons learned from the large-n models, which validate certain conjectures, to apply them to the case study. To avoid confusion, the term "variable" will not be used to mention all these elements, but rather we will speak of categories, classified in two groups, those related to underlying cooperation problems and characteristics of the actors (contextual categories) and those related to the design of the Agenda (design categories) (see Tables 2 and 3).

Table 2. Definition of contextual categories.

\begin{tabular}{cc}
\hline $\begin{array}{c}\text { Contextual Categories } \\
\text { (DIST) }\end{array}$ & $\begin{array}{c}\text { Definition } \\
\text { Distribution problem } \\
\text { over the distribution of outcomes of the potential agreement }\end{array}$ \\
\hline $\begin{array}{c}\text { Enforcement problem } \\
\text { (ENFO) }\end{array}$ & When states may have incentives to defect while the rest cooperate \\
\hline $\begin{array}{c}\text { Commitment problem } \\
\text { (COMM) }\end{array}$ & When there is a potential inconsistency between the present and the \\
future interests of a state
\end{tabular}

Table 3. Definition of design categories.

\begin{tabular}{cc}
\hline \multicolumn{1}{c}{ Design Categories } & Definition \\
\hline $\begin{array}{c}\text { Membership rules (MEMB) } \\
\text { Flexibility (FLEX) }\end{array}$ & $\begin{array}{c}\text { Refers to who belongs to the agreement and whether there are any } \\
\text { restrictions on access }\end{array}$ \\
\hline Centralization (CENT) & Refers to the ability to adapt to changes and unforeseen events \\
\hline Scope (SCOP) & Refers to the delegation and grouping of tasks \\
\hline Control (CONT) & Refers to which issues are included in the agreement \\
\hline
\end{tabular}

Source: Authors' own elaboration based on $[18,19]$.

A typical conjecture states that given a change in the context (for example, in the severity of the distribution problem), it is rational to expect that the design of the corresponding institution is going to change in certain direction, specified by the conjecture. Thus, to understand how the institutional design of the 2030 Agenda should be adapted to the COVID-19 scenario according to rationality, a first step is to identify how the situation of the contextual categories has been affected by the pandemic. To do so, we systematize the opinion shed by the international development policy 
experts in the 152 documents analyzed. Then, the application of the conjectures can inform about how the institutional design of the Agenda should be rationally adapted.

The systematization follows a content analysis technique: Argument mining. Content analysis has been defined as a research methodology that objectively and systematically describes the content of a given body of communication [52]. It has been commonly used to analyze policy-related topics (e.g., [53,54]). Argument mining is a technique that identifies argumentation structures in a discourse [55]. To this goal, the identification of types of arguments is crucial, which requires the use of software assisted by human coders to identify cooccurrences of individual arguments. In our study, we used NVIVO 12, a software commonly employed in qualitative research (e.g., [56,57]). We created a structure of categories ('codes' or 'nodes' in NVIVO terminology) that reflected the structure of our model, so we found no need of refining the codes [58]. Each document was read in its entirety and each piece of meaning that could be linked to one of those categories, according to the authors performing the process, was coded as such. This means that NVIVO assigns such pieces of text to each category, which allows its subsequent retrieval and analysis. Table 4 shows some examples of document pieces assigned to different categories.

Table 4. Selected examples of the codification process.

\begin{tabular}{|c|c|c|}
\hline Document. & Text & Assigned Category \\
\hline 23 & $\begin{array}{l}\text { Too often, governments have sequestered vaccines in the } \\
\text { countries where they were manufactured. We must ensure that } \\
\text { when an effective vaccine becomes available, it is accessible to } \\
\text { anyone who needs it, not just the rich, fortunate few. }\end{array}$ & Distribution problem \\
\hline 34 & $\begin{array}{l}\text { The fact that international help is not being rolled out suggests } \\
\text { either myopia by rich countries or the frightening prospect of a } \\
\text { world where people from poor and heavily infected countries } \\
\text { are banned from travelling-let alone migrating-to rich } \\
\text { countries, as in a de facto Apartheid where epidemic walls } \\
\text { replace physical walls. Such a scenario would represent the } \\
\text { collapse of one of the key pillars of current globalization. }\end{array}$ & Enforcement problem \\
\hline 132 & $\begin{array}{l}\text { The State Department has worked with other governments to } \\
\text { organize a global response to the coronavirus. In coordination } \\
\text { with the U.S. Agency for International Development (USAID), } \\
\text { it has delivered medical supplies and assistance to affected and } \\
\text { at-risk countries. As the pandemic worsened in the United } \\
\text { States, however, the White House task force essentially froze } \\
\text { USAID assistance after U.S. health workers faced PPE shortages. }\end{array}$ & Commitment problem \\
\hline
\end{tabular}

Source: Authors' own elaboration.

Being a qualitative procedure, this process of human coding presents a certain degree of subjectivity, given the impossibility of an a priori establishment of which terms correspond to each category, if only because of the existence of multiple synonyms and ways of expressing the same idea $[59,60]$.

For this reason, some precautions were taken to ensure rigor in our research regarding the validity and reliability of the process [61]. First, a clear definition of the categories was made (see Tables 2 and 3). Then, the authors ensured that they agreed on their understanding of each category, a relatively simple task since it is a model widely known in the literature [62]. Third, a sample of documents was assessed independently by two reviewers to ensure the control of bias [63]. No significant bias was detected. Fourth, we analyzed a set of 90 additional documents, from various sources, such as press editorials and documents from other international organizations not included in our sample. None of the documents analyzed showed elements of meaning essentially contradictory to any of our findings.

The following section will explain the results of the content analysis performed on the 152 documents to portray the main changes that the COVID-19 pandemic has introduced in the world and how they may hinder the international cooperation necessary for the successful implementation of the Agenda. 


\section{Results and Discussion}

Table 5 summarizes the main results of the content analysis performed. It shows how many pieces of text are related to each category, in how many documents each category appears, and which are the main documents cited in this section. In addition, the table reflects, in a very synthetic way, what the main changes or impacts that the categories will experience according to the experts' opinion are.

Table 5. Summary of the main results.

\begin{tabular}{ccccc}
\hline Category & \# Pieces of Text & \# Documents & Quoted Documents & Impact \\
\hline DIST & 23 & 19 & $23,24,27,80,85,107,111,117$ & Aggravated \\
ENFO & 54 & 34 & $30,34,42,66$ & Aggravated \\
COMM & 27 & 21 & $85,98,132,147$ & More evident \\
COOR & 54 & 31 & $34,104,117,126$ & Higher need of \\
shared action \\
UBEH & 40 & 20 & $44,66,87$ & Increased \\
USWO & 62 & 43 & $13,17,125$ & Increased \\
UPRE & 23 & 13 & $4,9,85,89,124,144$ & Increased \\
NUMB & 0 & 0 & N.A. & N.A. \\
PASY & 50 & 33 & $93,106,134,141,143,148$ & Likely to increase \\
DASY & 52 & 24 & $7,19,29,59,66,69,131$ & Risk of more \\
PHET & 44 & 26 & $22,34,70$ & Muthoritarianism \\
MEMB & 15 & 10 & $4,7,12,56,59,87,120$ & Key role of \\
FLEX & 4 & 1 & 1206 ont & Call for more \\
CENT & 54 & 32 & $8,12,17,33,34,56,70,75,138$ & Call for more \\
SCOP & 92 & 48 & $5,11,16,23,93,133,140,150$ & Risk of reduction \\
CONT & 0 & 0 & N.A. & N.A. \\
\hline
\end{tabular}

\subsection{The Impact of COVID-19 on the World}

Contextual categories can be classified into two groups. On the one hand, cooperation problems reflect how states' different interests and underlying uncertainties can influence the ability to reach and keep an agreement. On the other hand, the characteristics of the states, in terms of their number, preferences, power asymmetries, and government regime, may also influence the agreement. States' diverging interests give rise to distribution, enforcement, commitment, and coordination problems. Today, the deep changes that are taking place in the world generate changes in collective action, threatening international cooperation and multilateralism.

According to the experts, the coronavirus crisis has shown that some countries regard this situation as a win-lose game (23), so they feel compelled to direct their efforts (for example, in terms of funds or medical supplies, 24,85 ) inwards to protect their own citizens, at the expense of the rest of the world $(80,107,111,117)$. Therefore, the underlying distribution problems have been aggravated by COVID-19 (27).

The enforcement problem appears once an agreement is reached, giving rise to a classical repeated prisoners' dilemma situation [64]. When some countries decide to devote more resources to their own vulnerable population, they are somehow hindering the achievement of international development targets. The coronavirus has increased the number of free rider states in that sense because their selfish responses damage the global willingness to cooperate and consequently exacerbate the situation of developing countries $(30,34)$. Additionally, these actions may lead to a spiral of retaliation, undermining our capabilities to fight this and future pandemics $(34,42,66)$.

Some of the documents state that the current behavior of certain states, such as the US, shows that when subject to the stress of a crisis like this, their interest shifts to protecting themselves, clearly reflecting the existence of a commitment problem. Developed and developing countries are likely to 
withdraw funds from other SDGs to reinforce their health systems and protect their domestic lower-income population layers that suffer more from the consequences of the pandemic $(85,98,132,147)$.

As a global issue, the coronavirus requires a coordinated response. A single country not undertaking the actions necessary is enough to sabotage the efforts of the rest $(34,117)$. Therefore, all countries must agree on a common international approach, a clear coordination problem. Some experts extend this need for a shared action to other areas, such as climate change or poverty, because they are intimately linked to our capabilities to fight the virus $(104,126)$.

There is a clear uncertainty about the behavior of certain states, as some countries try to hide their real intentions and behavior regarding the coronavirus. COVID-19 has exacerbated an already existing uncertainty about behavior in countries such as China and Russia $(44,66)$. This factor is also linked to uncertainty about the state of the world. The regime destabilization strategy followed by some countries shows that they try to extend their influence on the world and, as a result, undermine the mutual trust needed to successfully fight the virus (87). Today, the world is more uncertain, not only because of the unknown consequences of the threat, but also because the behavior deployed by the international community makes it more difficult to foresee what will happen in the future, as developing countries are more likely to suffer the worst consequences $(13,17,125)$.

These two types of uncertainty are aggravated by a higher level of uncertainty about the preferences of the actors. Today, it is more difficult to ascertain what other countries want, and internal dissensions in many countries add to this source of uncertainty (89), especially in the US $(85,124)$. Another source of this uncertainty stems from the discrediting campaigns started by irresponsible politicians, which undermine our confidence in essential international institutions and political leaders $(4,9,144)$.

The number of states committed to international cooperation is starting to change. Even in an area such as the European Union (EU), unilateralism has taken place. Experts do not yet foresee how this change may affect fundamental aspects of cooperation, such as participation in international bodies or the volume of funds allocated to ODA. A withdrawal of high and middle-income countries would mean a paradigm shift that would curb the expectations of the most vulnerable. However, an opportunity could be opened up regarding the role of non-governmental actors, already present in the Agenda. It is possible that civil society will be called upon to defend cooperation and demand a more active role $(4,7,12,56,120)$.

Power asymmetries are going to increase the already-existing gap between developed and developing countries and, at the domestic level, between the rich and the poor $(134,141,143,148)$. The behavior of superpowers during the pandemic will determine their future importance in the international arena. For instance, the US will lose power and legitimacy, thus favoring the prominence of other countries (China, for instance; 93, 106).

Regarding domestic regime-type asymmetries, experts express their concern about the temptation to seek an authoritarian solution to the crisis, under the assumption that strict control and surveillance measures are needed to fight the pandemic at the expense of basic freedoms $(19,66)$, even in democratic countries $(7,131)$. However, some experts state that this assumption is not necessarily true $(29,59,69)$.

The pandemic has made evident some trends that were already present in the global arena $(7,19)$, one of which is this heterogeneity of interests among states, especially in terms of how they understand global governance. Some states call for the return to unilateralism or a reduced form of multilateralism, whereas other countries call for more cooperation $(22,34,70)$.

In summary, the experts' opinion points to significant changes in the international order resulting from changes in collective action. The problems faced by societies and the response they require alter the catalogue of interests and the behavior of actors. Economic inequalities will increase and developing countries will be the main losers. The interests of the actors will be more heterogeneous, and the formation of national preferences will tend to differ increasingly, so that the governance of the international system will become more complicated. 


\subsection{Implications for the Institutional Design of the 2030 Agenda}

Thus far, we have exposed the main changes in the world brought about by the pandemic. In this section, we will reflect on how these changes should be incorporated in the institutional design of the Agenda to remain a relevant frame of reference for multilateral cooperation. The analysis of the institutional design will follow the design categories, as seen in Table 3, and the way this design should be adapted to face the aforementioned changes in the contextual categories will be supported by a set of conjectures applicable to this case. To present the results, we first expose the evidence-based findings to date and then discuss their application to the Agenda.

\subsubsection{Membership Rules}

The first design category analyzed is membership rules. In the case of the 2030 Agenda, the formal members are the states that belong to the United Nations and that signed the founding agreement under the principle of universality. Other actors involved at the national level will not be considered within this section, as it refers only to the membership rules at the global level, but their role will be crucial for an effective localization of the Agenda.

Koremenos et al. [18] state that when the enforcement problem is severe, membership tends to be more restrictive because a greater number of actors makes cooperation more difficult [65]. The same happens with the uncertainty about states' preferences, especially when complying with the membership rules is costly, so those members that want to free ride will not join the agreement. Both conjectures share the same rationale: If states are likely to defect or their intentions are not clear, it is better to restrict their participation in the agreement. As Kydd notes [66], restrictive membership acts as a filter that lets out less-cooperative countries. On the other hand, a more severe distribution problem leads to inclusive membership because the zero-sum situation is alleviated when there are more members.

Given the universal and voluntary nature of the Agenda, reforms should tend to seek the lowest possible number of defections and give greater prominence to other non-governmental actors. Additionally, restricting membership will not solve the externalities generated by defecting countries in areas such as the environment or health, especially during a pandemic. Other solutions are available to address these problems, such as issue linkage, which will be reviewed in the scope section (3.2.4) [67]. There are intermediate options to avoid some states abandoning their commitments to the Agenda and to ODA that could be adopted without violating the principle of universality, for instance, to accept 'multi-speed' participation [68] in the implementation of the Agenda or to allow the possibility of prioritizing some goals over others and the available time frames. This proposal would have costs, probably more bearable than those of abandonment or indifference. With respect to high-income states, it would be necessary to seek compromise formulas that would allow implementation at the national level to be combined with the financing of ODA in similar terms.

On the other hand, experts have stressed the importance of civil society $(4,56,59,87)$ and international organizations $(4,7,12,56,120)$ in addressing the pandemic, so it might be advisable to give them more prominence at the global level, perhaps with new membership rules that recognize this fact.

In any case, membership rules do not seem to be the best option for adapting the institutional design of the 2030 Agenda to address the new scenario the world is currently facing.

\subsubsection{Flexibility}

When states fear the emergence of distributional problems during the implementation of an agreement, they would rather include more flexibility in it (106), for example, with escape clauses that allow for the non-performance of their commitments. Agreements made under conditions of uncertainty about the state of the world will be more flexible to adapt to future unknown circumstances. Finally, the greater the number of states in an agreement, the lower the flexibility will be; for example, 
if flexibility is understood as the possibility to renegotiate the conditions of the agreement, bargaining costs increase as the number of participants increase [18].

According to Koremenos [19], agreements with an underlying uncertainty about the state of the world are more likely to include finite duration or escape clauses, and these agreements tend to be shorter. The reason behind this is that the parties will prefer to renegotiate the agreement sooner or more often to adapt it to the shocks, or, alternatively, to temporarily withdraw from it, particularly when mere defection is an option. On the other hand, if there is an underlying coordination problem, agreements are more likely to be precise, as actors need to agree exactly on an issue, so it must be clearly stated in the agreement.

Regarding the 2030 Agenda, escape clauses and withdrawal provisions seem not necessary. However, perhaps the Agenda needs new forms of flexibility, especially if a deeper commitment from the states is needed [69], and more centralization is the answer that countries will give to the new scenario, as will be seen below. Baccini et al. [50] find that states will be more willing to cooperate if the agreement is endowed with higher flexibility. Vabulas and Snidal [70] show that flexibility is the solution when states do not want to make strong commitments under higher uncertainty and severe distribution problems, which is precisely the situation we are facing now. The world needs more commitment to the Agenda, but unless it is endowed with more flexibility, states will not agree to renouncing sovereignty.

The 2030 Agenda could be modified to include flexibility clauses that allow for a transformation of the agreement if future shocks (e.g., a new pandemic) make it necessary. We could also think of asymmetric impacts that do not require a full transformation of the Agenda but rather its adaptation in terms of, for example, escape clauses for those countries more affected by the shock, or the 'multi-speed' solution [71].

\subsubsection{Centralization}

The degree of the centralization of international agreements increases in situations of higher uncertainty, such that centralization is able to reduce political 'noise'. As the number of states participating in an agreement grows, the requirements of centralization are higher to reduce transaction costs, among other advantages. These conjectures refer mainly to centralized information, but there are other forms of centralization related to the coercive capacities of international organizations, so this type of centralization increases with the severity of the enforcement problem. Agreements are more likely to include dispute resolution provisions when they are characterized by an enforcement problem (as they increase the reputational costs of the violators and make punishments more credible), a commitment problem (they help governments tie the hands of their successors and allow other actors to punish any deviation from another state's announced plans), uncertainty about behavior, uncertainty about the state of the world, or a high number of actors (the latter three are situations in which a dispute is more likely to break out). Monitoring provisions appear more frequently when there is uncertainty about behavior or when there are many actors in the agreement (because in both cases, more information is needed). In the former case, self-reporting is found when there are few incentives to defect, for obvious reasons.

Experts have expressed that some form of international institutionalized governance is the best way to address a global crisis of this nature, such as the coronavirus $(17,33,34,70)$. The delegation of coordination functions to a focal entity, both at national and international levels, is considered paramount for effective action $(12,17,56,75)$. Regarding the 2030 Agenda, the underlying uncertainty, enforcement, and commitment problems indicate the need for a higher level of centralization of authority. It seems that the Agenda was not initially designed to match the conjectures about centralization, because although the prevailing situation when it was formulated had clear cooperation problems, the option was the opposite, namely, to decentralize, which reflected a more constructivist than rational approach. 
Now that many of the aforementioned cooperation problems are aggravated, the rational approach and many experts in our database recommend a higher level of centralization to share better information at the very least. Asymmetric centralization is possible, with more formal arrangements where cooperation problems are more severe [70].

The 2030 Agenda has decentralization as one of its characteristics, but only at the national level. Some experts have presented experiences of how decentralization may have a paramount role to address the pandemic at community level in areas that national or global initiatives may not reach, precisely where vulnerable populations live $(8,138)$. Therefore, although conjectures recommend more centralization at the global level, perhaps this should be combined with some local decentralization.

Regarding monitoring provisions, self-reporting may not be enough when the incentives to defect are high, so some sort of delegated monitoring arrangement could be designed, perhaps performed by independent bodies, such as NGOs [49,72], at global, national, and local levels.

With respect to dispute settlement mechanisms, disputes linked to environment or health problems (to quote only a couple of areas) will be more likely in the future, thus endangering the attainment of the SDGs. Therefore, it is rational to think that the world should establish more formal dispute resolution mechanisms to address these conflicts and support the SDGs. This could mean merely reinforcing the existing arrangements, linking them more directly to the Agenda, or creating new ones. An institutionalized entity could be designed, receiving the delegation of authority from the states to perform different centralized functions, not only dispute settlement.

Bernauer et al. [51] show that centralization provisions may encourage or discourage participation. For example, monitoring and enforcement mechanisms decrease participation due to implementation costs and sovereignty concerns, whereas dispute settlement mechanisms have a positive effect. The rational approach has solutions to the discouragement caused by certain centralization provisions, such as issue linkage (see below) or different control mechanisms [73]. If the 2030 Agenda is modified to include more centralization, other measures should also be taken to guarantee that the vast majority of states remain involved.

\subsubsection{Scope}

Koremenos et al. [18] state that issue scope should increase given the current situation, with greater heterogeneity among a larger number of actors, more severe distribution problems, and more severe enforcement problems. Issue linkage is the main reason to have a wide scope, as it offers a zone of possible agreement.

According to Mitchell and Keilbach [67], when externalities are asymmetric, the distribution and enforcement problems are more severe, and positive issue linkage (exchange) could be the best way to address them, irrespective of the victim being strong or weak.

Therefore, the rational approach suggests that the scope of the Agenda should not be reduced, despite the temptations to do so. One of the dangers of the coronavirus shock is that states may be tempted to focus only on those areas that are more directly linked to the threat, abandoning the rest $(16,23,93,140)$. There are three reasons to avoid this behavior. First, the conjectures of the rational approach already quoted. Second, we have seen above how issue linkage may function as a lever to ease the introduction of other measures needed to address the new situation, such as more centralization. Third, following some of the experts' statements, health is not a one-dimensional but rather a manifold phenomenon, with physical and psychological linkages [74]. Poverty, environment, education, and gender, to quote only a few, are areas intrinsically linked to health [75], making it impossible to improve the latter without considering its interactions with the former $(5,11,133,150)$. Therefore, rationally, the Agenda should maintain wide scope to address the new challenges posed by the coronavirus, which cannot be faced solely under a strictly health-focused approach. 


\subsubsection{Control}

Control exerted by individual actors decreases as the number of actors in the agreement increases. A higher asymmetry of power among states generates a higher asymmetry of control, which is translated as a kind of design or procedural asymmetry [19]. It is easy to understand that states that are considered more important (and thus bring more value to an institution), expect to receive more from the agreement, and subsequently, try to impose their power to guarantee that return (for example, Graham [76,77] analyzes how powerful donors introduce funding rules in UN institutions to have more control).

Blake and Payton [78] analyze intergovernmental organizations in different areas and find that when states' core interests are at stake, majoritarian voting rules are more frequent, whereas in situations when it is important to secure the participation of important actors, weighted voting systems are chosen. To encourage flexibility, states will avoid unanimity voting rules in institutions with large membership.

In the same direction, Hooghe and Marks [79] assert that an organization with a large number of veto players is more difficult to reform, so institutions with many members should avoid national veto and formalize supermajority decision rules. They also analyze the effect of the interface between the scope of the institution and the domestic politics on the veto rules, so states will be less willing to give up their veto power when the decisions of the international institution may have an impact on them.

This crisis will widen the gap between rich and poor countries, thus increasing asymmetries of power among them. According to the rational approach, this should lead to control asymmetries. Is it likely to happen in the 2030 Agenda? There are three complementary scenarios where this higher asymmetry of power could be accepted, with the common feature that the interface between the domestic and the international arenas will increase in the future, with conflicts of interest that are in the very nature of the Agenda. This means that veto powers will most likely remain in the hands of those powerful states that do not want to defect from their international aid commitments, but do not want to have their hands tied when a shock arrives.

In the first scenario, countries accept more centralization or delegation of functions (see above), but powerful states will only be willing to give up sovereignty to some kind of centralized institution if they keep some control over the agreement. The second scenario is the 'multi-speed' solution mentioned above, in which ad hoc voting rules would probably be adopted. In the third scenario, if important donors of cooperation for development aid want to make sure that recipient countries adopt certain behavior (in terms of the allocation of funds to improve their health systems, for instance), they could implement conditioned aid procedures, which means de facto that donors have control over the Agenda.

Another issue that should be addressed with regard to control is the role of non-governmental actors. What power should they have within the framework of the Agenda? Perhaps these actors could be a factor of balance between the different states' interests and a factor of external control over government decisions, something that is in fact already being done. Many of these organizations combine the global, national, and local levels and can therefore be key stakeholders in harmonizing the implementation of the Agenda at these three levels.

\section{Conclusions}

After analyzing the experts' opinion about the changes that COVID-19 can bring about in the governance of the 2030 Agenda, we can infer that the projected future governance scenarios constitute a threat to its implementation both at the national and international levels. The causes must be sought in the foreseeable change in the behavior of governments in the face of scenarios of greater risk and uncertainty and their negative impact on multilateral cooperation, a fundamental pillar of the Agenda. In a situation like this, the non-binding nature of the resolution and the limited functionality of the institutional design of the Agenda will probably make it a highly contingent instrument. The analysis of the contextual categories points to the relevance of greater institutionalization and legalization, establishing more binding and precise rules and greater delegation of authority. 
The conjectures that we develop on the design categories suggest the rational adaptation of the Agenda to the new reality, reformulating the terms of membership and flexibility to avoid desertion or disengagement of some key states. This could be achieved especially through agreements that allow for 'multi-speed' implementation and greater involvement of civil society and other nongovernmental actors, something that is also proposed by some experts.

Another of the more relevant ideas suggested by our research is the establishment of greater levels of centralization of authority through the delegation of functions such as coordination, monitoring, and evaluation and dispute settlement to focal bodies or entities with different levels of formality, a recurrent idea in the documents. This formula offers advantages for the maintenance of the states' commitments in terms of cooperation and adaptation to crisis scenarios. It reduces political tension and allows for the development and reformulation of more functional rules. It can counteract the incentives of governments to violate the constitutive agreement, for example, by making their positions public and exposing their public image to the international community. Also, it would enable the incorporation of new non-governmental actors who bring other interests and more flexible policy formulas to international relations. Nevertheless, this is a problematic solution because it implies the cession of sovereignty, and the most powerful actors will tend to exercise their control over the agreement, but there are other intergovernmental solutions that have proved their worth in recent decades.

The adaptation of the Agenda presents different scenarios for change that indicate feasible ways out of the crisis. In the first, the option to maintain multilateral cooperation is the most accepted by experts, but it entails a renegotiation of agreements that will probably require a substantial modification of expectations. A second scenario confirming the trend towards uni- or bilateralism would probably lead to a paradigm shift that would undo the advances of the last decades and make the world even more unequal, unfair, and insecure. Finally, an atomized scenario that combines the above would probably keep the Agenda alive but would surely break the principles of universality and integrality, with consequences on multi-actor governance. It would probably fail to live up to the motto of 'leave no one behind' because the most vulnerable would certainly be left behind.

Our study is limited by at least three aspects: First, the database of international development experts may have some globalist bias, although the sample of think tanks is relatively diverse; second, a more in-depth analysis of the institutional design of the Agenda from a legalization approach that more accurately determines the aspects of obligation, precision, and delegation [80] is still pending in academia; and third, given this article's vocation to collect early reactions, there is not yet a sufficient time horizon to determine whether changes in governance will take place and whether international actors will effectively adopt a rational behavior. This is precisely one of the future lines of research.

Author Contributions: Conceptualization, F.S.-C., L.A.F.-P. and A.S.; methodology, L.A.F.-P. and A.S.; formal analysis, L.A.F.-P.; investigation, F.S.-C., L.A.F.-P. and A.S.; resources, F.S.-C.; data curation, F.S.-C.; writing-original draft preparation, F.S.-C., L.A.F.-P. and A.S.; writing-review and editing, F.S.-C., L.A.F.-P. and A.S. All authors have read and agreed to the published version of the manuscript.

Funding: This research received no external funding.

Conflicts of Interest: The authors declare no conflict of interest. 


\section{Appendix A}

Table A1. Documents used for the analysis.

\begin{tabular}{|c|c|c|c|c|}
\hline Code & Date & Title & Author's Name & Source \\
\hline 1 & $16 / 03 / 20$ & Countering the Coronavirus: can people remain safe and still practice their faith? & Mariz Tadros & Institute of Development Studies \\
\hline 2 & $15 / 04 / 20$ & Covid-19 - the experience of living a pandemic rather than researching one & Annie Wilkinson & Institute of Development Studies \\
\hline 3 & $08 / 04 / 20$ & Covid-19 in low-income countries - we need rapid learning about effective handwashing initiatives & Jamie Myers & Institute of Development Studies \\
\hline 4 & $03 / 04 / 20$ & COVID-19 may be the ultimate test of science and policy partnerships & James Georgalakis & Institute of Development Studies \\
\hline 5 & $06 / 04 / 20$ & Covid-19 reveals and further increases inequalities in water and sanitation & Lyla Metha et al. & Institute of Development Studies \\
\hline 6 & $02 / 04 / 20$ & $\begin{array}{l}\begin{array}{l}\text { Excessive health damage from Covid-19 will be followed by excessive wealth damage unless } \\
\text { governments act now }\end{array} \\
\end{array}$ & Michael Lipton & Institute of Development Studies \\
\hline 7 & $08 / 04 / 20$ & Fear of a fragile planet & Naomi Hossain & Institute of Development Studies \\
\hline 8 & $25 / 03 / 20$ & Lessons from Brazil for the global response to COVID-19 & Alex Shankland & Institute of Development Studies \\
\hline 9 & $16 / 03 / 20$ & Science, uncertainty and the COVID-19 response & Ian Scoones & Institute of Development Studies \\
\hline 10 & $24 / 03 / 20$ & Strengthening Brazilian partnerships in the face of Covid-19 & Alex Shankland and Rachel Dixon & Institute of Development Studies \\
\hline 11 & $21 / 03 / 20$ & With climate change impacts accelerating, we need to re-think the human right to water & $\begin{array}{l}\text { Lila Metha, Claudia Ringler and } \\
\text { Shiney Varghese }\end{array}$ & Institute of Development Studies \\
\hline 12 & $01 / 04 / 20$ & Lessons from Covid-19: building more effective health services for a complex future & Gerald Bloom & Institute of Development Studies \\
\hline 13 & $20 / 03 / 20$ & COVID-19 - a social phenomenon requiring diverse expertise & Haylee MacGregor et al. & Institute of Development Studies \\
\hline 14 & $23 / 03 / 20$ & Precarious and informal work exacerbates spread of coronavirus & Ayako Ebata et al. & Institute of Development Studies \\
\hline 15 & $14 / 04 / 20$ & How COVID-19 will change the nation's long-term economic trends, according to Brookings Metro scholars & Mark Muro et al. & Brookings Institution \\
\hline 16 & $23 / 03 / 20$ & A mortality perspective on COVID-19. Time, location, and age & Katharina Fenz and Homi Kharas & Brookings Institution \\
\hline 17 & $11 / 04 / 20$ & Africa in the news. COVID-19 impacts African economies and daily lives; clashes in the Sahel & $\begin{array}{l}\text { Dhruv Gandhi, Anna Schaeffer, } \\
\text { and Payce Madden }\end{array}$ & Brookings Institution \\
\hline 18 & $04 / 04 / 20$ & Africa in the news. Impacts of COVID-19 on African economies and elections updates & $\begin{array}{l}\text { Christina Golubski and } \\
\text { Anna Schaeffer }\end{array}$ & Brookings Institution \\
\hline 19 & $26 / 03 / 20$ & Brookings experts on the implications of COVID-19 for the Middle East and North Africa & $\begin{array}{l}\text { Tarik M. Yousef, Ranj Alaaldin, } \\
\text { Geneive Abdo et al. }\end{array}$ & Brookings Institution \\
\hline 20 & $27 / 03 / 20$ & $\begin{array}{l}\text { COVID-19. Does India have enough doctors? An analysis of growing COVID-19 patients and existing } \\
\text { medical capacity }\end{array}$ & $\begin{array}{l}\text { Prachi Singh, Dweepobotee } \\
\text { Brahma, and Sikim Chakraborty }\end{array}$ & Brookings Institution \\
\hline 21 & $24 / 03 / 20$ & COVID-19. Is India's health infrastructure equipped to handle an epidemic & $\begin{array}{l}\text { Prachi Singh, Shamika Ravi, } \\
\text { and Sikim Chakraborty }\end{array}$ & Brookings Institution \\
\hline
\end{tabular}


Table A1. Cont.

\begin{tabular}{|c|c|c|c|c|}
\hline Code & Date & Title & Author's Name & Source \\
\hline 22 & $12 / 03 / 20$ & COVID-19 is a reminder that interconnectivity is unavoidable & $\begin{array}{l}\text { Morgan D. Bazilian and } \\
\text { Samantha Gross }\end{array}$ & Brookings Institution \\
\hline 23 & $02 / 04 / 20$ & Ebola lessons for fighting COVID-19 & Ngozi Okonjo-Iweala & Brookings Institution \\
\hline 24 & $08 / 04 / 20$ & Understanding the impact of the COVID-19 outbreak on the Nigerian economy & $\begin{array}{l}\text { Chukwuka Onyekwena and } \\
\text { Mma Amara Ekeruche }\end{array}$ & Brookings Institution \\
\hline 25 & $03 / 04 / 20$ & Who are the workers already impacted by the COVID-19 recession & Alan Berube and Nicole Bateman & Brookings Institution \\
\hline 26 & $06 / 04 / 20$ & How the EU and rising powers can shape their future sustainably & Sven Grimm et al. & German Development Institute \\
\hline 27 & $02 / 04 / 20$ & $\begin{array}{l}\text { Curb your enthusiasm: Corona may slow down multilateral process, but must not derail } \\
\text { global climate policy }\end{array}$ & Clara Brandi et al. & German Development Institute \\
\hline 28 & $09 / 04 / 20$ & How the corona crisis is calling into question the "right to the city & Eva Dick & German Development Institute \\
\hline 29 & $01 / 04 / 20$ & Parallels between the corona pandemic and climate change & Hanna Fuhrmann and Sascha Kuhn & German Development Institute \\
\hline 30 & $23 / 03 / 20$ & Coronavirus as an opportunity for international cooperation & Paul Marschall and Wulf Reiners & German Development Institute \\
\hline 31 & $02 / 04 / 20$ & What we can learn from and about Africa in the corona crisis & Michael Roll & German Development Institute \\
\hline 32 & $30 / 03 / 20$ & How we will need to tackle climate migration post-coronavirus & Benjamin Schraven & German Development Institute \\
\hline 33 & $26 / 03 / 20$ & Why social protection is crucial in the corona crisis & $\begin{array}{l}\text { Christoph Strupat, Francesco } \\
\text { Burchi and Daniele Malerba }\end{array}$ & German Development Institute \\
\hline 34 & $01 / 04 / 20$ & Lessons for Global Cooperation from the COVID-19 Pandemic & Gianluca Grimalda & German Development Institute \\
\hline 35 & $03 / 04 / 20$ & An Uncertain Recovery & Verónica Ortíz-Ortega & Wilson Center \\
\hline 36 & $19 / 03 / 20$ & Canada's Response to Coronavirus & Mariana Sánchez-Ramírez & Wilson Center \\
\hline 37 & $16 / 04 / 20$ & COVID-19 and the Threat to the North American Economy & James Haley & Wilson Center \\
\hline 38 & $20 / 03 / 20$ & COVID-19: The Global Evil & Verónica Ortíz-Ortega & Wilson Center \\
\hline 39 & $17 / 03 / 20$ & Exploring the Complexity of Pandemics Through Play & Elizabeth Newbury & Wilson Center \\
\hline 40 & $23 / 03 / 20$ & Home-Clinic to Face COVID-19 in Mexico & Luis de la Calle & Wilson Center \\
\hline 41 & $14 / 04 / 20$ & How Will Southeast Asia's Conflict Zones Fare in 2020 and beyond? & Prashanth Parameswaran & Wilson Center \\
\hline 42 & $23 / 03 / 20$ & If Games are Postponed, Japan Can Still Bring a World in Pain Together & Shihoko Goto & Wilson Center \\
\hline 43 & $30 / 03 / 20$ & Mexico's Energy Policy in times of Covid-19? & Lourdes Melgar & Wilson Center \\
\hline 44 & $01 / 04 / 20$ & Moscow-Driven “Forced Reintegration" Scenario Endangers Ukraine's National Security & Igor Popov & Wilson Center \\
\hline 45 & $17 / 03 / 20$ & News Roundup: The MENA Region in the Time of COVID-19 & $\begin{array}{l}\text { Merissa Khurma and } \\
\text { Alexander Farley }\end{array}$ & Wilson Center \\
\hline 46 & $24 / 03 / 20$ & Projected Impact of COVID-19 on Ukraine's Economy & Adrian Prokip & Wilson Center \\
\hline 47 & $08 / 04 / 20$ & Rebuilding Public Trust in International Aviation: An Opportunity for U.S.-Canada Leadership & Solomon Wong and Marcelo Garcia & Wilson Center \\
\hline 48 & $26 / 03 / 20$ & Reports from North America's Borders: Experts React to New COVID-19 Travel Restrictions & Jon Barela et al. & Wilson Center \\
\hline 49 & $17 / 03 / 20$ & Russia and Eurasia Respond to the Pandemic & Morgan Jacobs & Wilson Center \\
\hline
\end{tabular}


Table A1. Cont.

\begin{tabular}{|c|c|c|c|c|}
\hline Code & Date & Title & Author's Name & Source \\
\hline 50 & $07 / 04 / 20$ & Russia's "Special Path" in the Global Pandemic & Sergey Parkhomenko & Wilson Center \\
\hline 51 & $27 / 03 / 20$ & Russia's Chinese Dream in the Era of COVID-19 & Emily Couch & Wilson Center \\
\hline 52 & $10 / 04 / 20$ & South Korea's Parliamentary Elections: Key Variables and Their Implications & Soojin Park & Wilson Center \\
\hline 53 & $27 / 03 / 20$ & Survival: Venezuela and the Coronavirus & Beatriz García-Nice & Wilson Center \\
\hline 54 & $23 / 03 / 20$ & The First Days of COVID-19 in Ukraine & Yuriy Vakhel & Wilson Center \\
\hline 55 & $09 / 04 / 20$ & Ukraine Quarterly Digest: January-March 2020 & Andrian Prokip & Wilson Center \\
\hline 56 & $07 / 04 / 20$ & $\begin{array}{l}\text { Using tech to fight the virus: How much privacy are South Koreans relinquishing in the battle } \\
\text { against COVID-19? }\end{array}$ & Jean H. Lee & Wilson Center \\
\hline 57 & $02 / 04 / 20$ & Washington versus Moscow: Official responses to Covid-19 & Grigory Vaipan & Wilson Center \\
\hline 58 & $24 / 03 / 20$ & What Lies Behind Russia's Coronavirus Containment Effort & Judy L. Twigg & Wilson Center \\
\hline 59 & $31 / 03 / 20$ & What the U.S. Can Learn from Asia's Coronavirus Response & Alex Long & Wilson Center \\
\hline 60 & $24 / 03 / 20$ & Will COVID Redefine the East Asian Miracle? & Shihoko Goto & Wilson Center \\
\hline 61 & $24 / 03 / 20$ & Wilson Center Experts Weigh in on the Coronavirus & $\begin{array}{l}\text { Cynthia J. Arnson, Diana Villiers, } \\
\text { Christopher Sands }\end{array}$ & Wilson Center \\
\hline 62 & $10 / 04 / 20$ & Women's Choice: COVID-19 or an Abusive Partner & Olimpiada Usanova & Wilson Center \\
\hline 63 & $17 / 03 / 20$ & What Coronavirus Means for South Asia & Michael Kugelman & Wilson Center \\
\hline 64 & $27 / 03 / 20$ & Ukrainians Keep Their Composure During the COVID-19 Epidemic & Semen Gluzman & Wilson Center \\
\hline 65 & $10 / 04 / 20$ & Downtrodden in a Shut Down & Aníbal Nicolás Saldías & Wilson Center \\
\hline 66 & $09 / 04 / 20$ & COVID-19 Brings Human Rights into Focus & Sonya Sceats & Chatham House \\
\hline 67 & $29 / 03 / 20$ & In a COVID-19 World, Russia Sticks to International Distancing & Mathieu Boulègue & Chatham House \\
\hline 68 & $09 / 04 / 20$ & Beware Russian and Chinese Positioning for After the Pandemic & Keir Giles & Chatham House \\
\hline 69 & $31 / 03 / 20$ & Coronavirus and the Future of Democracy in Europe & Hans Kundnani & Chatham House \\
\hline 70 & $16 / 04 / 20$ & How to survive the pandemic & Creon Butler & Chatham House \\
\hline 71 & $16 / 03 / 20$ & America's Coronavirus Response Is Shaped By Its Federal Structure & Leslie Vinjamuri & Chatham House \\
\hline 72 & $15 / 04 / 20$ & Blaming China Is a Dangerous Distraction & Jim O’Neill & Chatham House \\
\hline 73 & $06 / 04 / 20$ & Can Morocco Effectively Handle the COVID-19 Crisis? & $\begin{array}{l}\text { Mohammed Masbah and } \\
\text { Anna Jacob }\end{array}$ & Chatham House \\
\hline 74 & $16 / 03 / 20$ & Coronavirus: All Citizens Need an Income Support & Jim O’Neill & Chatham House \\
\hline 75 & $15 / 03 / 20$ & Coronavirus: Global Response Urgently Needed & $\begin{array}{l}\text { Jim O’Neill, Robin Niblett, } \\
\text { Creon Butler }\end{array}$ & Chatham House \\
\hline 76 & $18 / 03 / 20$ & Coronavirus: Why The EU Needs to Unleash The ECB & Pepijn Berssen & Chatham House \\
\hline 77 & $07 / 04 / 20$ & COVID 19: Assessing Vulnerabilities and Impacts on Iraq & $\begin{array}{l}\text { Renad Mansour, Mac Skelton and } \\
\text { Abdulameer Mohsin Hussein }\end{array}$ & Chatham House \\
\hline
\end{tabular}


Table A1. Cont.

\begin{tabular}{|c|c|c|c|c|}
\hline Code & Date & Title & Author's Name & Source \\
\hline 78 & $15 / 04 / 20$ & Emerging Infections in Perspective: Novel Coronavirus and H7N9 Influenza & David Heymann & Chatham House \\
\hline 79 & $02 / 04 / 20$ & Emerging Lessons From COVID-19 & Jim O`Neill & Chatham House \\
\hline 80 & $26 / 03 / 20$ & Let's Emerge From COVID-19 with Stronger Health Systems & Robert Yates & Chatham House \\
\hline 81 & $24 / 03 / 20$ & The G20's Pandemic Moment & Jim O’Neill & Chatham House \\
\hline 82 & $16 / 04 / 20$ & Belarusians Left Facing COVID-19 Alone & Ryhor Astapenia and Anais Marin & Chatham House \\
\hline 83 & $08 / 04 / 20$ & COVID-19 and the Iranian Shadows of War & Sanam Vakil & Chatham House \\
\hline 84 & $31 / 03 / 20$ & COVID-19 Impact on Refugees is Also Political & Lina Khatib & Chatham House \\
\hline 85 & $06 / 04 / 20$ & In Search of the American State & Leslie Vinjamuri & Chatham House \\
\hline 86 & $01 / 04 / 20$ & Predictions and Policymaking: Complex Modelling Beyond COVID-19 & Yasmin Afina and Calum Inverarity & Chatham House \\
\hline 87 & $02 / 04 / 20$ & Supporting NHS Cybersecurity During COVID-19 is Vital & Joyce Hakmeh & Chatham House \\
\hline 88 & $15 / 04 / 20$ & Why an Inclusive Circular Economy is Needed to Prepare for Future Global Crises & Patrick Schröder & Chatham House \\
\hline 89 & $06 / 04 / 20$ & An Eroding European Union & Heather A. Conley & $\begin{array}{l}\text { Center for Strategic and } \\
\text { International Studies }\end{array}$ \\
\hline 90 & $15 / 04 / 20$ & Australia Goes Hard and Goes Early on Covid-19 & Parick Gerard Buchan & $\begin{array}{l}\text { Center for Strategic and } \\
\text { International Studies }\end{array}$ \\
\hline 91 & $15 / 04 / 20$ & China's External Sector: Imagining the Post- Covid-19 Reality & Kevin Nealer & $\begin{array}{l}\text { Center for Strategic and } \\
\text { International Studies }\end{array}$ \\
\hline 92 & $13 / 04 / 20$ & China's Digital Silk Road after the Coronavirus & $\begin{array}{l}\text { Jude Blanchette and } \\
\text { Jonathan E. Hillman }\end{array}$ & $\begin{array}{c}\text { Center for Strategic and } \\
\text { International Studies }\end{array}$ \\
\hline 93 & $27 / 03 / 20$ & Competition or Coordination: Coronavirus in the Developing World & $\begin{array}{l}\text { Daniel F. Runde; } \\
\text { Sundar Ramanujan }\end{array}$ & $\begin{array}{l}\text { Center for Strategic and } \\
\text { International Studies }\end{array}$ \\
\hline 94 & $03 / 04 / 20$ & Cooperation, Not Fear, Keeps the Food Supply Chain Secure & Caitlin Welsh & $\begin{array}{l}\text { Center for Strategic and } \\
\text { International Studies }\end{array}$ \\
\hline 95 & $18 / 03 / 20$ & Coronation, Coronavirus, and the Economy: The Economic Backdrop of a Fifth Putin Term & Cyrus Newlin & $\begin{array}{l}\text { Center for Strategic and } \\
\text { International Studies }\end{array}$ \\
\hline 96 & $03 / 04 / 20$ & Covid-19 and Value Chains: Diminishing Returns from Trade Policy & Scott Miller & $\begin{array}{l}\text { Center for Strategic and } \\
\text { International Studies }\end{array}$ \\
\hline 97 & $10 / 04 / 20$ & Covid-19 at Sea: Impacts on the Blue Economy, Ocean Health, and Ocean Security & $\begin{array}{l}\text { Whitley Saumweber and } \\
\text { Amy K. Lehr }\end{array}$ & $\begin{array}{l}\text { Center for Strategic and } \\
\text { International Studies }\end{array}$ \\
\hline 98 & $06 / 04 / 20$ & Covid-19 Exposes Latin America's Inequality & Linnea Sandin & $\begin{array}{l}\text { Center for Strategic and } \\
\text { International Studies }\end{array}$ \\
\hline 99 & $18 / 03 / 20$ & COVID-19 Is an African Political Crisis as Much as a Health and Economic Emergency & Judd Devermont & $\begin{array}{l}\text { Center for Strategic and } \\
\text { International Studies }\end{array}$ \\
\hline 100 & $25 / 03 / 20$ & COVID-19 Is Attacking Our Defense Supply Chains and Our Nation's Security & Andrew Philip Hunter & $\begin{array}{l}\text { Center for Strategic and } \\
\text { International Studies }\end{array}$ \\
\hline
\end{tabular}


Table A1. Cont.

\begin{tabular}{|c|c|c|c|c|}
\hline Code & Date & Title & Author's Name & Source \\
\hline 101 & $06 / 04 / 20$ & Donald Trump Is Right. We Need 'BIG \& BOLD' Infrastructure Spending & Lachlan Carey & $\begin{array}{l}\text { Center for Strategic and } \\
\text { International Studies }\end{array}$ \\
\hline 102 & $02 / 04 / 20$ & Emergency Planning for OPEC States & Ben Cahill & $\begin{array}{l}\text { Center for Strategic and } \\
\text { International Studies }\end{array}$ \\
\hline 103 & $26 / 03 / 20$ & Empowering Women through Skills and Workforce Development & $\begin{array}{c}\text { Daniel F. Runde; } \\
\text { William J. Garvelink and } \\
\text { Janina Staghun }\end{array}$ & $\begin{array}{l}\text { Center for Strategic and } \\
\text { International Studies }\end{array}$ \\
\hline 104 & $09 / 04 / 20$ & Energy and Emissions after Covid-19: A First Cut & Sarah Ladislaw and Nikos Tsafos & $\begin{array}{l}\text { Center for Strategic and } \\
\text { International Studies }\end{array}$ \\
\hline 105 & $13 / 04 / 20$ & Europe Is at War with the Coronavirus. Where Does That Leave European Defense? & Quentin Lopinot & $\begin{array}{l}\text { Center for Strategic and } \\
\text { International Studies }\end{array}$ \\
\hline 106 & $23 / 03 / 20$ & Europe's Coronavirus Test & $\begin{array}{l}\text { Quentin Lopinot and } \\
\text { Donatienne Ruy }\end{array}$ & $\begin{array}{l}\text { Center for Strategic and } \\
\text { International Studies }\end{array}$ \\
\hline 107 & $16 / 04 / 20$ & Find My Friends in a Pandemic: e Future of Contact Tracing in America & Anna Carroll & $\begin{array}{c}\text { Center for Strategic and } \\
\text { International Studies }\end{array}$ \\
\hline 108 & $25 / 03 / 20$ & Five Ways COVID-19 Is Changing Global Migration & Erol Yaiboke & $\begin{array}{c}\text { Center for Strategic and } \\
\text { International Studies }\end{array}$ \\
\hline 109 & $13 / 04 / 20$ & Latin America: On the Verge of an Unprecedented Turn in the Covid-19 Pandemic? & Michael A. Matera & $\begin{array}{c}\text { Center for Strategic and } \\
\text { International Studies }\end{array}$ \\
\hline 110 & $02 / 04 / 20$ & NATO Responds to the Covid-19 Pandemic & Rachel Ellehuus & $\begin{array}{c}\text { Center for Strategic and } \\
\text { International Studies }\end{array}$ \\
\hline 111 & $02 / 04 / 20$ & Pandemic Pandemonium: How the Virus Could Change the Trading System & William Alan Reisch & $\begin{array}{c}\text { Center for Strategic and } \\
\text { International Studies }\end{array}$ \\
\hline 112 & $31 / 03 / 20$ & Putin and the COVID Crisis: Instability as Opportunity & Iain King and Rachel Ellehuus & $\begin{array}{l}\text { Center for Strategic and } \\
\text { International Studies }\end{array}$ \\
\hline 113 & $02 / 04 / 20$ & Seeking a Path to Europe, Refugees and Migrants Ultimately Turned Back by Covid-1 & $\begin{array}{c}\text { Erol Yaboke and } \\
\text { Joseph S. Bermúdez Jr. }\end{array}$ & $\begin{array}{l}\text { Center for Strategic and } \\
\text { International Studies }\end{array}$ \\
\hline 114 & $09 / 04 / 20$ & Supporting Mozambique's Response to the Growing Insurgent threat in Cabo Delgado & Emila Columbo & $\begin{array}{l}\text { Center for Strategic and } \\
\text { International Studies }\end{array}$ \\
\hline 115 & $14 / 04 / 20$ & The Economic Toll of Covid 19 & Amy Searight & $\begin{array}{l}\text { Center for Strategic and } \\
\text { International Studies }\end{array}$ \\
\hline 116 & $30 / 03 / 20$ & The End of OPEC or a New Beginning? & Sara Ladislaw & $\begin{array}{l}\text { Center for Strategic and } \\
\text { International Studies }\end{array}$ \\
\hline 117 & $08 / 04 / 20$ & The G20 Agreement the World Needs Now & Sara Ladislaw & $\begin{array}{l}\text { Center for Strategic and } \\
\text { International Studies }\end{array}$ \\
\hline 118 & $08 / 04 / 20$ & The Mexican Government's Response to Covid-19 Is Insufficient & Gladis MacKormick & $\begin{array}{l}\text { Center for Strategic and } \\
\text { International Studies }\end{array}$ \\
\hline
\end{tabular}


Table A1. Cont.

\begin{tabular}{|c|c|c|c|c|}
\hline Code & Date & Title & Author's Name & Source \\
\hline 119 & 19/03/20 & Time to Call Off the Oil War & $\begin{array}{l}\text { Frank A. Verrastro; Larry Goldstein } \\
\text { and Albert Hermig }\end{array}$ & $\begin{array}{l}\text { Center for Strategic and } \\
\text { International Studies }\end{array}$ \\
\hline 120 & $20 / 03 / 20$ & U.S.-China Relations and COVID-19: What Can Be Done Now & John L. Holden & $\begin{array}{l}\text { Center for Strategic and } \\
\text { International Studies }\end{array}$ \\
\hline 121 & $01 / 04 / 20$ & Which Covid-19 Future Will We Choose? & $\begin{array}{l}\text { J. Stephen Morrison and } \\
\text { Anna Carroll }\end{array}$ & $\begin{array}{c}\text { Center for Strategic and } \\
\text { International Studies }\end{array}$ \\
\hline 122 & $07 / 04 / 20$ & Will Covid-19 End the Age of Mass Protests? & Samuel Brannen & $\begin{array}{l}\text { Center for Strategic and } \\
\text { International Studies }\end{array}$ \\
\hline 123 & $08 / 04 / 20$ & Fuel Shortages during Covid-19 in Venezuela & $\begin{array}{l}\text { Moisés Rendón and } \\
\text { Margarita Seminario }\end{array}$ & $\begin{array}{l}\text { Center for Strategic and } \\
\text { International Studies }\end{array}$ \\
\hline 124 & $15 / 04 / 20$ & What's on the Horizon for Covid-19? & J. Stephen Morrison et al. & $\begin{array}{l}\text { Center for Strategic and } \\
\text { International Studies }\end{array}$ \\
\hline 125 & $31 / 03 / 20$ & Geopolitical Scenarios for Asia after COVID-19 & Michael J. Green & $\begin{array}{l}\text { Center for Strategic and } \\
\text { International Studies }\end{array}$ \\
\hline 126 & $27 / 03 / 20$ & Africa and the Third Wave of Covid-19 & Neil Anthony Webster & $\begin{array}{c}\text { Danish Institute for } \\
\text { International Studies }\end{array}$ \\
\hline 127 & $31 / 03 / 20$ & Asia beyond China & Luke Patey & $\begin{array}{l}\text { Danish Institute for } \\
\text { International Studies }\end{array}$ \\
\hline 128 & $01 / 04 / 20$ & COVID-19: A Looming humanitarian disaster for Somali East Africa & Abdirahman Edle Ali et al. & $\begin{array}{c}\text { Danish Institute for } \\
\text { International Studies }\end{array}$ \\
\hline 129 & $10 / 04 / 20$ & Women This Week: The Gendered Effects of COVID-19 & Maleeha Coleman et al. & Council on Foreign Relations \\
\hline 130 & $06 / 04 / 20$ & At War With a Virus & Richard N. Haas & Council on Foreign Relations \\
\hline 131 & $16 / 03 / 20$ & China and Coronavirus: From Home-Made Disaster to Global Mega-Opportunity & Joshua Kurlantzick & Council on Foreign Relations \\
\hline 132 & $07 / 04 / 20$ & U.S. Coronavirus Response: Who's In Charge of What? & Lindsay Maizland & Council on Foreign Relations \\
\hline 133 & $07 / 04 / 20$ & COVID-19 and lockdowns Are women more affected? & Bina Agarwal & $\begin{array}{l}\text { United Nations University } \\
\text { (UNU-WIDER) }\end{array}$ \\
\hline 134 & $02 / 04 / 20$ & Estimates of the impact of COVID-19 on global poverty & Andy Sumner et al. & $\begin{array}{l}\text { United Nations University } \\
\text { (UNU-WIDER) }\end{array}$ \\
\hline 135 & $10 / 04 / 20$ & Age composition of population and Covid-19 & Kunal Sen & $\begin{array}{l}\text { United Nations University } \\
\text { (UNU-WIDER) }\end{array}$ \\
\hline 136 & $08 / 04 / 20$ & Is Mozambique prepared for a lockdown during the COVID-19 pandemic? & $\begin{array}{l}\text { Sam Jones, Eva Maria Egger and } \\
\text { Ricardo Santos }\end{array}$ & $\begin{array}{l}\text { United Nations University } \\
\text { (UNU-WIDER) }\end{array}$ \\
\hline 137 & $06 / 04 / 20$ & To die from hunger or the virus. An all too real dilemma for the poor in India & Marty Chen & $\begin{array}{l}\text { United Nations University } \\
\text { (UNU-WIDER) }\end{array}$ \\
\hline 138 & $16 / 03 / 20$ & When COVID-19 comes to Africa & Arkebe Oqubay & $\begin{array}{l}\text { United Nations University } \\
\text { (UNU-WIDER) }\end{array}$ \\
\hline
\end{tabular}


Table A1. Cont.

\begin{tabular}{|c|c|c|c|c|}
\hline Code & Date & Title & Author's Name & Source \\
\hline 139 & $14 / 04 / 20$ & Countries facing Covid-19 debt need flexible financing: lessons from China & Arkebe Oqubay & $\begin{array}{l}\text { United Nations University } \\
\text { (UNU-WIDER) }\end{array}$ \\
\hline 140 & $01 / 04 / 20$ & Covid-19 and trade: challenges ahead for Least Developed Countries and Small Island Developing State & Jodie Keane & Overseas Development Institute \\
\hline 141 & $01 / 04 / 20$ & Covid-19: 'we won't get back to normal because normal was the problem' & Sara Pantuliano & Overseas Development Institute \\
\hline 142 & $20 / 03 / 20$ & Covid-19: five lessons from Ebola & Sorcha O'Callaghan & Overseas Development Institute \\
\hline 143 & $18 / 03 / 20$ & Financing for developing countries facing a coronavirus-sparked economic crisis & Jesse Griffiths & Overseas Development Institute \\
\hline 144 & $17 / 03 / 20$ & Governments must catch up to curb the coronavirus pandemic & Arkebe Oqubay & Overseas Development Institute \\
\hline 145 & $26 / 03 / 20$ & How coronavirus is accelerating a new approach to international cooperation & Annalisa Prizzon & Overseas Development Institute \\
\hline 146 & $09 / 04 / 20$ & "Libya and pandemic politics in armed conflicts & Sherine El Taraboulsi-McCarthy & Overseas Development Institute \\
\hline 147 & $16 / 04 / 20$ & Migrant key workers: time to act & Marta Foresti & Overseas Development Institute \\
\hline 148 & $27 / 03 / 20$ & The G20's coronavirus action plan must help the poorest countries & Dirk Willem te Velde & Overseas Development Institute \\
\hline 149 & $07 / 04 / 20$ & What research from conflict-affected countries can tell us about responses to Covid-19 & Mareike Shomerus & Overseas Development Institute \\
\hline 150 & $02 / 04 / 20$ & Hotspots of vulnerability in times of crisis & Vidya Diwakar & Overseas Development Institute \\
\hline 151 & $02 / 04 / 20$ & How to scale up multilateral financing to face the Covid-19 crisis & Chris Humphrey & Overseas Development Institute \\
\hline 152 & $03 / 04 / 20$ & The coronavirus pandemic and the governance of global value chains: emerging evidence & Jodie Keane & Overseas Development Institute \\
\hline
\end{tabular}

Source: Authors' own elaboration based on [43]. 


\section{References}

1. United Nations. Transforming Our World: The 2030 Agenda for Sustainable Development; United Nations: New York, NY, USA, 2015.

2. Lundsgaarde, E.; Keijzer, N. Development Cooperation in a Multilevel and Multistakeholder Setting: From Planning towards Enabling Coordinated Action? Eur. J. Dev. Res. 2019, 31, 215-234. [CrossRef]

3. HLPE. Impact of COVID-19 on Food Security and Nutrition (FSN). 2020. Available online: http://www.fao. org/fileadmin/templates/cfs/Docs1920/Chair/HLPE_English.pdf (accessed on 18 August 2020).

4. Renn, O. The Call for Sustainable and Resilient Policies in the COVID-19 Crisis: How Can They Be Interpreted and Implemented? Sustainability 2020, 12, 6466. [CrossRef]

5. Sianes, A.; Santos-Carrillo, F.; Fernández-Portillo, L.A. Agreements and disagreements in the EU's cooperation policy with Central America. Rev. CIDOB Afers Int. 2018, 119-145. [CrossRef]

6. Martínez-Osés, P.; Martínez, I. La Agenda 2030: ¿Cambiar el mundo sin cambiar la distribución del poder? Lan Harremanak Rev. Relac. Labor. 2016, 73-102. [CrossRef]

7. United Nations. Progress towards the Sustainable Development Goals. Report of the Secretary-General (E/2018/64). 2018. Available online: https://undocs.org/E/2018/64 (accessed on 18 August 2020).

8. Naciones Unidas. Naciones Unidas/CEPAL La Agenda 2030 y los Objetivos de Desarrollo Sostenible: Una Oportunidad para América Latina y el Caribe. Objetivos, Metas e Indicadores Mundiales; Naciones Unidas: Santiago de Chile, Chile, 2019.

9. Barbier, E.B.; Burgess, J.C. Sustainability and development after COVID-19. World Dev. 2020, 135, 105082. [CrossRef] [PubMed]

10. Oldekop, J.A.; Horner, R.; Hulme, D.; Adhikari, R.; Agarwal, B.; Alford, M.; Bakewell, O.; Banks, N.; Barrientos, S.; Bastia, T.; et al. COVID-19 and the case for global development. World Dev. 2020, 134, 105044. [CrossRef]

11. Aust, A. Handbook of International Law; Cambridge University Press: Cambridge, UK, 2010.

12. Álvarez, J.E. The Impact of International Organizations on International Law; Brill/Nijhoff: Leiden, The Netherlands, 2017.

13. White, N.D. The Law of International Organisations; Juris Publishing-Manchester University Press: Manchester, UK, 2005.

14. Keohane, R. Neoliberal Institutionalism: A Perspective on World Politics. In International Institution and State Power; Westview Press: London, UK, 1989.

15. Finnemore, M.; Sikkink, K. International Norm Dynamics and Political Change. Int. Organ. 1998, 52, 887-917. [CrossRef]

16. Ostrom, E. Governing the Commons: The Evolution of Institutions for Collective Action; Cambridge University Press: Cambridge, UK, 1990.

17. Martin, L.L.; Simmons, B.A. International Organizations and Institutions. In Handbook of International Relations; Carisnaes, W., Risse, T., Simmons, B.A., Eds.; SAGE Publications: London, UK, 2013; pp. 326-351.

18. Koremenos, B.; Lipson, C.; Snidal, D. The rational design of international institutions. Int. Organ. 2001, 761-799. [CrossRef]

19. Koremenos, B. The Continent of International Law: Explaining Agreement Design; Cambridge University Press: Cambridge, UK, 2016.

20. Westerwinter, O. Transnational public-private governance initiatives in world politics: Introducing a new dataset. Rev. Int. Organ. 2019. [CrossRef]

21. Abbott, K.W.; Bernstein, S. The High-Level Political Forum on Sustainable Development: Orchestration by Default and Design. Glob. Policy 2015, 6, 222-233. [CrossRef]

22. Kratochwil, F.; Ruggie, J.G. International organization: A state of the art on an art of the state. Int. Organ. 1986, 40, 753-775. [CrossRef]

23. Ruggie, J.G. Multilateralism: The Anatomy of an Institution. Int. Organ. 1992, 46, 561-598. [CrossRef]

24. Reus-Smit, C. (Ed.) The Politics of International Law; Cambridge University Press: Cambridge, UK, 2004.

25. Keohane, R.O. After Hegemony. Cooperation and Discord in the World Political Economy; Princeton University Press: Princeton, NJ, USA, 1984.

26. Abbott, K.W.; Keohane, R.O.; Moravcsik, A.; Slaughter, A.M.; Snidal, D. The Concept of Legalization. Int. Organ. 2000, 54, 401-419. [CrossRef] 
27. Rosendorff, B.P. Stability and rigidity: Politics and design of the WTO's dispute settlement procedure. Am. Polit. Sci. Rev. 2005, 99, 389-400. [CrossRef]

28. Goodin, R.E. (Ed.) The Theory of Institutional Design; Cambridge University Press: Cambridge, UK, 1996.

29. Pierson, P. The limits of design: Explaining institutional origins and change. Governance 2000, 13, 475-499. [CrossRef]

30. Wendt, A. Driving with the rearview mirror: On the rational science of institutional design. Int. Organ. 2001, 55, 1019-1049. [CrossRef]

31. Duffield, J.S. The limits of "rational design". Int. Organ. 2003, 57, 411-430. [CrossRef]

32. Koremenos, B. Contracting around International uncertainty. Am. Polit. Sci. Rev. 2005, 99, 549-565. [CrossRef]

33. Haas, P.M. Do regimes matter? Epistemic communities and mediterranean pollution control. Int. Organ. 1989, 43, 377-403. [CrossRef]

34. Adler, E. The emergence of cooperation: National epistemic communities and the international evolution of the idea of nuclear arms control. Int. Organ. 1992, 46, 101-145. [CrossRef]

35. Adler, E.; Haas, P.M. Conclusion: Epistemic communities, world order, and the creation of a reflective research program. Int. Organ. 1992, 46, 367-390. [CrossRef]

36. Smith, M.; Marden, P. Conservative think tanks and public politics. Aust. J. Polit. Sci. 2008, 43, 699-717. [CrossRef]

37. Coman, R. Why and how do think tanks expand their networks in times of crisis? The case of Bruegel and the Centre for European Policy Studies. J. Eur. Public Policy 2019, 26, 286-301. [CrossRef]

38. Stone, D. Think tanks, global lesson-drawing and networking social policy ideas. Glob. Soc. Policy 2001, 1, 338-360. [CrossRef]

39. Fraussen, B.; Halpin, D. Think tanks and strategic policy-making: The contribution of think tanks to policy advisory systems. Policy Sci. 2017, 50, 105-124. [CrossRef]

40. Arshed, N. The origins of policy ideas: The importance of think tanks in the enterprise policy process in the UK. J. Bus. Res. 2017, 71, 74-83. [CrossRef]

41. Ladi, S.; Lazarou, E.; Hauck, J. Brazilian think tanks and the rise of austerity discourse. Policy Soc. 2018, 37, 222-242. [CrossRef]

42. Kelstrup, J.D. Quantitative differences in think tank dissemination activities in Germany, Denmark and the UK. Policy Sci. 2017, 50, 125-137. [CrossRef]

43. McGann, J.G. 2019 Global Go to Think Tank Index Report; The Lauder Institute University of Pennsylvania: Philadelphia, PA, USA, 2020.

44. Shaw, S.E.; Russell, J.; Parsons, W.; Greenhalgh, T. The view from nowhere? How think tanks work to shape health policy. Crit. Policy Stud. 2015, 9, 58-77. [CrossRef]

45. Haas, E. False equivalency: Think tank references on education in the news media. Peabody J. Educ. 2007, 82, 63-102. [CrossRef]

46. McCright, A.M.; Dunlap, R.E. Challenging Global Warming as a Social Problem: An Analysis of the Conservative Movement's Counter-Claims. Soc. Probl. 2000, 47, 499-522. [CrossRef]

47. Boussalis, C.; Coan, T.G. Text-mining the signals of climate change doubt. Glob. Environ. Chang. 2016, 36, 89-100. [CrossRef]

48. Riffe, D.; Stephen, L.; Frederick, F. Analyzing Media Messages: Using Quantitative Content Analysis in Research, 2nd ed.; Lawrence Erlbaum Associates: Mahwah, NJ, USA, 2005.

49. Koremenos, B. If only half of international agreements have dispute resolution provisions, which half needs explaining? J. Legal Stud. 2007, 36, 189-212. [CrossRef]

50. Baccini, L.; Dür, A.; Elsig, M. The Politics of Trade Agreement Design: Revisiting the Depth-Flexibility Nexus. Int. Stud. Q. 2015, 59, 765-775. [CrossRef]

51. Bernauer, T.; Kalbhenn, A.; Koubi, V.; Spilker, G. Is There a "Depth versus Participation" Dilemma in International Cooperation? Rev. Int. Organ. 2013, 8, 477-497. [CrossRef]

52. Berelson, B. Content Analysis in Communication Research, 1st ed.; The Free Press of Glencoe: New York, NY, USA, 1952.

53. Karremans, J. Political alternatives under European economic governance: Evidence from German budget speeches (2009-2019). J. Eur. Public Policy 2020. [CrossRef]

54. Chinn, S.; Hart, P.S.; Soroka, S. Politicization and Polarization in Climate Change News Content, $1985-2017$. Sci. Commun. 2020, 42, 112-129. [CrossRef] 
55. Walton, D.; Koszowy, M. From text to scheme: Problems in identifying arguments from expert opinion. Int. Rev. Pragmat. 2019, 11, 109-136. [CrossRef]

56. Hilton, S.; Buckton, C.H.; Patterson, C.; Vittal Katikireddi, S.; Lloyd-Williams, F.; Hyseni, L.; Elliott-Green, A.; Capewell, S. Following in the footsteps of tobacco and alcohol? Stakeholder discourse in UK newspaper coverage of the Soft Drinks Industry Levy. Public Health Nutr. 2019, 22, 2317-2328. [CrossRef]

57. Herrmann, A.; Sauerborn, R.; Nilsson, M. The role of health in households' balancing act for lifestyles compatible with the paris agreement-Qualitative results from Mannheim, Germany. Int. J. Environ. Res. Public Health 2020, 17, 1297. [CrossRef]

58. Barbour, R.S. Quality of Data Analysis. In The SAGE Handbook of Qualitative Data Analysis; Flick, U., Ed.; SAGE Publications Inc.: London, UK, 2014; pp. 496-509. ISBN 9781446208984.

59. Brown, D.; Taylor, C.; Baldy, G.; Edwards, G.; Oppenheimer, E. Computers and QDA—Can they help it? A report on a qualitative data analysis programme. Sociol. Rev. 1990, 38, 140-150. [CrossRef]

60. Neuendorf, K.A.; Kumar, A. Content Analysis. In The International Encyclopedia of Political Communication; Mazzoleni, G., Ed.; Wiley Blackwell: Chichester, UK, 2016; pp. 221-230. ISBN 9781118290750.

61. Maher, C.; Hadfield, M.; Hutchings, M.; Eyto, A. Ensuring Rigor in Qualitative Data Analysis: A Design Research Approach to Coding Combining NVivo With Traditional Material Methods. Int. J. Qual. Methods 2018, 17. [CrossRef]

62. Schreier, M. Qualitative Content Analysis. In The SAGE Handbook of Qualitative Data Analysis; Flick, U., Ed.; SAGE Publications Inc.: London, UK, 2014; pp. 170-183. ISBN 9781446208984.

63. Weber, R.P. Basic Content Analysis; SAGE Publications Inc.: London, UK, 1990; ISBN 9780803938632.

64. Fearon, J.D. Bargaining, enforcement, and international cooperation. Int. Organ. 1998, 52, 269-305. [CrossRef]

65. Olson, M. The Logic of Collective Action; Harvard University Press: Cambridge, MA, USA, 1965.

66. Kydd, A. Trust building, trust breaking: The dilemma of NATO enlargement. Int. Organ. 2001, 55, 801-828. [CrossRef]

67. Mitchell, R.B.; Keilbach, P.M. Situation Structure and Institutional Design. Int. Organ. 2001, 55, 891-917. [CrossRef]

68. Gaynor, K.B.; Karakitsos, E. Economic Convergence in a Multispeed Europe; Palgrave Macmillan: London, UK, 1997.

69. Kucik, J.; Reinhardt, E. Does flexibility promote cooperation? An application to the global trade regime. Int. Organ. 2008, 62, 477-505. [CrossRef]

70. Vabulas, F.; Snidal, D. Organization without delegation: Informal intergovernmental organizations (IIGOs) and the spectrum of intergovernmental arrangements. Rev. Int. Organ. 2013, 8, 193-220. [CrossRef]

71. Thompson, A. Rational design in motion: Uncertainty and flexibility in the global climate regime. Eur. J. Int. Relat. 2010, 16, 269-296. [CrossRef]

72. Mitchell, R.B. Sources of Transparency: Information Systems in International Regimes. Int. Stud. Q. 1998, 42, 109-130. [CrossRef]

73. Richards, J.E. Institutions for flying: How states built a market in international aviation services. Int. Organ. 2001, 55, 993-1017. [CrossRef]

74. Mucci, F.; Mucci, N.; Diolaiuti, F. Lockdown and isolation: Psychological aspects of COVID-19. Clin. Neuropsychiatry 2020, 17, 63-64. [CrossRef]

75. Lidskog, R.; Elander, I. COVID-19, the Climate, and Transformative Change: Comparing the Social Anatomies of Crises and Their Regulatory Responses. Sustainability 2020, 12, 6337. [CrossRef]

76. Graham, E.R. Money and multilateralism: How funding rules constitute IO governance. Int. Theory 2015, 7, 162-194. [CrossRef]

77. Graham, E.R. The institutional design of funding rules at international organizations: Explaining the transformation in financing the United Nations. Eur. J. Int. Relat. 2017, 23, 365-390. [CrossRef]

78. Blake, D.J.; Payton, A.L. Balancing design objectives: Analyzing new data on voting rules in intergovernmental organizations. Rev. Int. Organ. 2015, 10, 377-402. [CrossRef]

79. Hooghe, L.; Marks, G. Delegation and pooling in international organizations. Rev. Int. Organ. 2015, 10, 305-328. [CrossRef]

80. Abbott, K.W.; Snidal, D. Hard and Soft Law in International Governance. Int. Organ. 2000, 54, 421-456. [CrossRef] 